\title{
First report of Quaternary mammals from the Qalehjough area, Lut Desert, Eastern Iran
}

\author{
Narges Hashemi, Alireza Ashouri, Mansour Aliabadian, \\ M.H. Mahmudy Gharaie, Antonio Sánchez Marco, and Julien Louys
}

\begin{abstract}
Taxonomic study of Quaternary mammal remains from the Qalehjough fossil site, eastern Iran, has resulted in the identification of two mammal orders, Artiodactyla and Perissodactyla, with four families and six taxa. Of particular note was the recovery of Stephanorhinus and a caballoid horse. These remains have provided the first opportunity to examine Late Quaternary faunal assemblages in the northern parts of the Lut Desert, eastern Iran. The Qalehjough faunal assemblage documents some zoogeographic characteristics of the eastern Iranian Plateau, and suggests that palaeoenvironments in this part of Iran during the Pleistocene were more humid and wooded than today. The disappearance of rhinoceroses and caballoid horses from this region is most likely a result of climate change and concomitant habitat loss.
\end{abstract}

Narges Hashemi. Department of Geology, International Campus, Ferdowsi University of Mashhad, Mashhad, Iran. nhashemi.bi_geol@yahoo.com

Alireza Ashouri. Department of Geology, Faculty of Science, Ferdowsi University of Mashhad, Mashhad, Iran. Corresponding author. ashouri@um.ac.ir Mansour Aliabadian. Department of Biology, Faculty of Science, Ferdowsi University of Mashhad, Mashhad, Iran; and Research Department of Zoological Innovations (RDZI), Institute of Applied Zoology, Faculty of Sciences, Ferdowsi University of Mashhad, Mashhad, Iran. Second corresponding author. aliabadi@um.ac.ir

M.H. Mahmudy Gharaie. Department of Geology, Faculty of Science, Ferdowsi University of Mashhad, Mashhad, Iran. mhmgharaie@um.ac.ir

Antonio Sánchez Marco. Catalan Institute of Paleontology Miquel Crusafont, Barcelona, Spain.

Antoni.sanchez@icp.cat

Julien Louys. Department of Archaeology and Natural History, School of Culture, History, and Languages, ANU College of Asia and the Pacific, Coombs Building, The Australian National University, Canberra ACT 2601. Julien.louys@anu.edu.au

Keywords: Quaternary; eastern Iran; paleoenvironment; Perissodactyla; Artiodactyla

Submission: 9 February 2015 Acceptance: 31 August 2016

Hashemi, Narges, Ashouri, Alireza, Aliabadian, Mansour, Gharaie, M.H. Mahmudy, Sánchez Marco, Antonio, and Louys, Julien. 2016. First report of Quaternary mammals from the Qalehjough area, Lut Desert, Eastern Iran. Palaeontologia Electronica 19.3.44A: 1-12 palaeo-electronica.org/content/2016/1622-quaternary-mammals-of-iran

Copyright: () November 2016 Society of Vertebrate Paleontology. This is an open access article distributed under the terms of the Creative Commons Attribution License, which permits unrestricted use, distribution, and reproduction in any medium, provided the original author and source are credited. creativecommons.org/licenses/by/4.0/ 


\section{INTRODUCTION}

Climatic change has been a major factor affecting the distribution of mammals throughout the Quaternary. This geological period is characterized by pronounced environmental changes resulting from fluctuations between interglacial and glacial stages (Kehl, 2009), and these are likely to have significantly affected the distribution and extinction of many large-bodied mammals throughout the world (e.g., Wroe et al., 2013; Louys et al., 2007; Louys, 2014; Faith, 2014). The Holocene in particular is marked by the absence of many terrestrial mammals that became extinct by the end of the Pleistocene (e.g., Redding, 1978). Late Quaternary extinctions have been explained through the actions of several mechanisms including environmental changes (Martin and Klein, 1984; MacPhee, 1999; Guthrie, 2003); habitat loss (King and Saunders, 1984; Barnosky, 1986; Ficcarelli et al., 2003); mosaic-nutrient hypotheses (Guthrie, 1984); co-evolutionary disequilibrium (Graham and Lundelius, 1984); self-organized instability (Forster, 2004); or a combination of these (Martin and Klein, 1984; Barnosky, 1989; Stuart, 1991, 1999; Stuart et al., 2004), and potentially in association with human impacts (Martin and Klein, 1984; MacPhee, 1999). In addition, anthropogenic extinction models, including overkill, blitzkrieg (rapid overkill) (Mosimann and Martin, 1975) and sitzkrieg (fire, habitat fragmentation, and the introduction of exotic species and diseases) have been considered plausible explanations for extinctions in and of themselves. Despite global analyses, the nature and causes of Pleistocene extinctions in Iran have never been examined.

Central and eastern Iran's current climate is diverse, from arid or semiarid (about $75 \%$ of the country), to subtropical along the Caspian coast (Kehl, 2009), to very hot and dry interior areas (Alijani et al., 2008). As such, faunal communities in different parts of Iran differ considerably. The Iranian Plateau is located in the Palearctic realm and sits in a region of major zoogeographical interchange between Europe and Asia, and as such hosts diverse climatic and environmental conditions (Moradi et al., 2010). An understanding of the natural history of this area is critical for modern zoogeographical studies, and palaeontological research in this area forms a critical component. Nevertheless, vertebrate palaeontological studies in Iran remain rare.

One of the first and most important discoveries of Pleistocene vertebrates from Quaternary

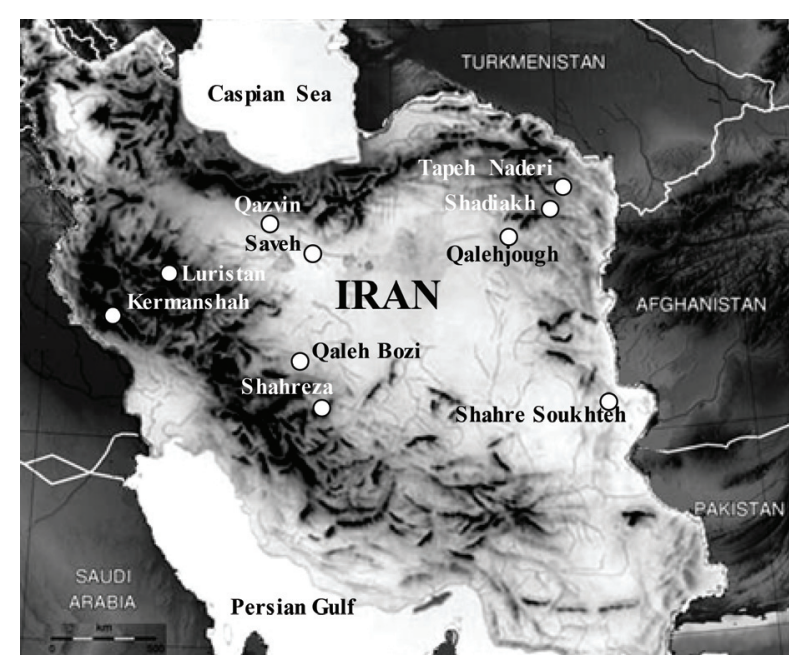

FIGURE 1. Locations of the Qalehjough fossil site, near Faizabad of Khorassan Razavi province, and other Quaternary fossil sites in Iran. Fossil vertebrate assemblages from these sites consist of following elements ( $E$ = Equus, $\mathrm{R}=\mathrm{Rhinocerotidae}$, and $\mathrm{C}=$ Caprinae): Qalehjough $(E, R, C)$, Tapeh Naderi $(E, C)$, Shadiakh (E, C), Qazvin (E, R, C), Saveh (E, R), Luristan (E), Qaleh bozi $(E, R, C)$, Kermanshah $(E, R)$, Shahreza $(E)$, and Shahre Soukhteh (E).

sediments in Iran dates to the mid-nineteenth century (Farshad, 1959). After several hiatuses in palaeontological research in Iran during the twentieth century, studies of late Quaternary vertebrate deposits have been conducted on remains recovered from alluvial sediments, and caves or rock shelters, most of which were located in western and north-western Iran. Such faunal assemblages have yielded remains of rhinos (Kermanshah, Saveh and Qaleh bozi), Asiatic asses (Equus hemionus), caprinines (Ovis and Capra), and gazelles (Kermanshah, Saveh, Qaleh bozi, Shahreza, Qazvin, Tapeh Naderi, Shadiakh, and Share soukhteh) (Farshad, 1959; Mirzaie Ataabadi, 2000; Hashemi et al., 2006; Otte et al., 2007; Hashemi and Darvish, 2008; Hashemi et al., 2010; Hashemi, 2012) (Figure 1). However, despite some renewed research into Iran's palaeontological heritage, relatively little is known of the vertebrate diversity of eastern Iran. With this problem in mind, investigations in to the palaeontological potential of Quaternary sediments from the Qalehjough area were recently undertaken. This study describes the initial results of this investigation. These finds provide insights into the nature of faunal diversity and environments in the northern parts of the Lut Desert, eastern Iran, during the Quaternary. 

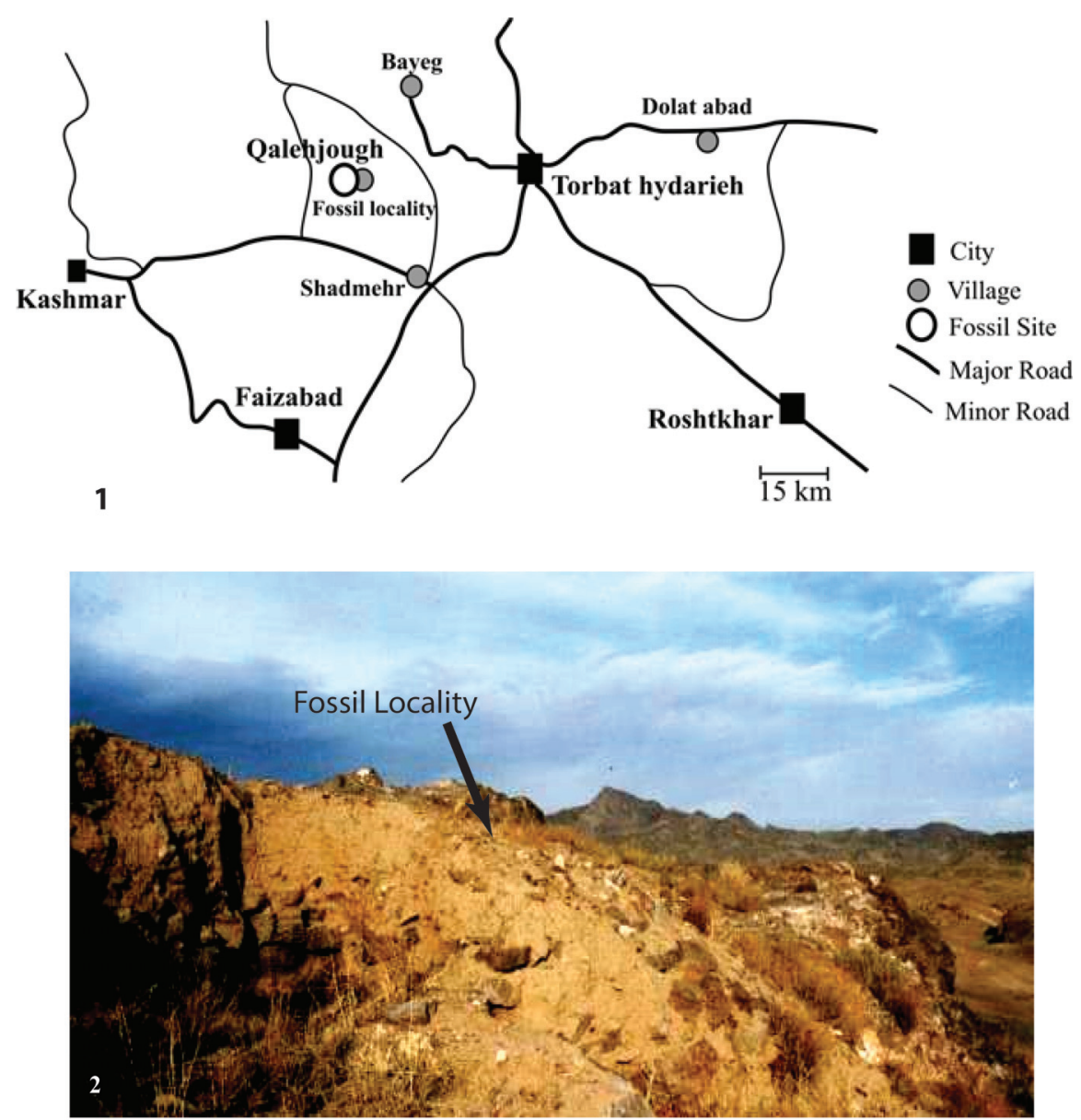

FIGURE 2. 1, Map depicting major cities and local villages around the Qalehjough fossil site. 2, Photograph of the fossil bearing sediments (photographed by Narges Hashemi).

\section{MATERIALS AND METHODS}

The Qalehjough fossil site (QHJ), with an elevation of $1,420 \mathrm{~m}$ above sea level, is located at $57^{\circ} 55^{\prime}$ $\mathrm{E}$ and $35^{\circ} 18^{\prime} \mathrm{W}$ in the northern part of Lut Desert, about $32 \mathrm{~km}$ to the west of Torbat Hydaieh in geological province of Faizabad (Figure 2.1). The site is located on the southern exposures of the Cheltan Mountain (3,013 m elevation), and in an agriculture region near to a seasonal river in an area that extends approximately one kilometer in diameter (Hashemi, 2006). The site is characterized by late Quaternary deposits including alluvial sediments, red conglomerate, and andesite to pyroxene andesite (Figure 2.2). Basal Neogene deposits in this region are characterized by brown conglomerates varying in thickness from centimetres to one metre, with clasts typically well-rounded and cemented within a calcareous matrix. The majority of the fossils were derived from red conglomerate beds that dominate the section (Figure $3)$.
Among the fossil specimens recovered from the site, 47 were identifiable to taxa. They consisted of both cranial (mandible and isolated teeth) and postcranial elements. For each specimen, taxon, element, and portion of that element, anatomical location and condition of the bone (including any notes on age death) were recorded. Some material was measured individually using a slide gauge with a Vernier scale. Morphological comparisons and assessments of dental wear stages of the fossil material were made using the collection of FUM. Information from the following literature was also used to aid in the identification and measurement of the fossils (Payne, 1969; Boessneck, 1969; Von den Driesch, 1976; Eisenmann, 1986; Hillson, 1986; Prummel and Frisch, 1986; Helmer and Rocheteaux, 1994; Buitenhuis, 1995; Halstead et al., 2002; Deng, 2008, 2009; Zeder and Lapham, 2010; Gillis et al., 2011). The number of identified specimens (NISP) and total number fragments (TNF) were evaluated. The fossil material 


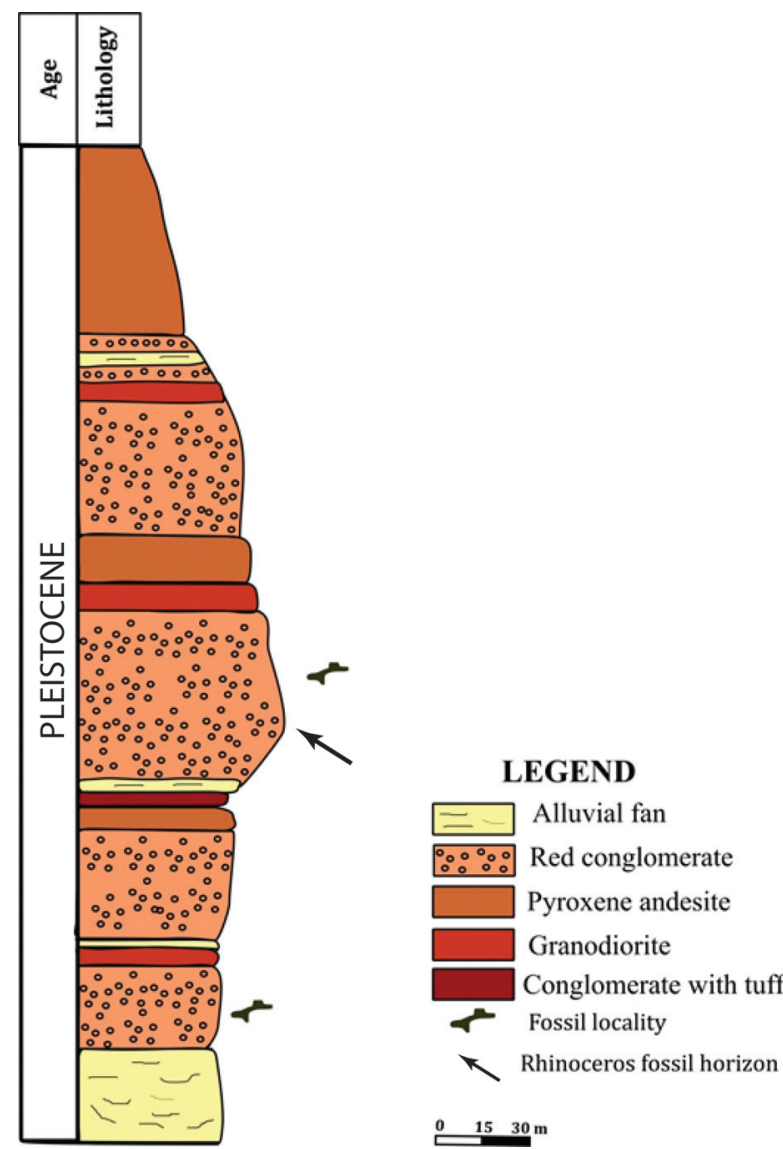

FIGURE 3. Stratigraphic section and the situation of fossil occurrence in Qalehjough fossil site (drawn by Narges Hashemi).

investigated here are housed in the Ferdowsi University of Mashhad Museum, Iran (FUM).

\section{SYSTEMATIC PALAEONTOLOGY}

Order PERISSODACTYLA Owen, 1848

Family RHINOCEROTIDAE Gray, 1821

Genus STEPHANORHINUS Kretzoi, 1942

Stephanorhinus cf. kirchbergensis Jäger, 1839

Figure 4.1-2, Table 1

Material. One right $\mathrm{P}^{4}$ (but see the text below) (QHJ-45).

Description. This tooth is rectangular in occlusal outline. It is broken anteriorly, and the original shape may be more squared. The lingual margin of the protocone is rounded and bulbously inflated, whereas the buccal side possesses a weak fold. Due to the heavy wear on the tooth, it is separated from the hypocone only by the enamel medial margins of the respective lingual cusps. The metaloph is long, wide, and oblique posteriorly, with a visible small fold in the lingual portion. The complex enamel patterning of the occlusal surface shows that in the crown of the tooth two principal tracts of dentine were present and not filled up by cement. The buccal portion of the ectoloph has a straight margin. A strongly developed crochet curves out at a right angle from the anterior margin of the metaloph and juts buccally before making contact with the lingual margin of the ectoloph. The occlusal surface of the tooth is relatively smooth with a small fracture in the lingual side more than the other sides. In lateral view, it is strongly ectolophodont, with the buccal margin of the tooth significantly higher than the lingual side.

Remarks. Due to its overall dimensions and degree of wear and completeness, this tooth is provisionally identified as a $\mathrm{P}^{4}$, although it could be a $P^{3}$. It is assigned to Stephanorhinus on the basis of its extreme molarisation, presence of a well-developed crochet, bulbous protocone, degree of hypsodonty, and smooth ectoloph. Owing to the lack of other preserved diagnostic characters, it impossible to provide a confident species diagnosis. However, on the basis of its dimensions, the lack of antecrochet, angle between crochet and metaloph (Lacombat, 2006), as well as its age and geographical location, we consider it comparable to $S$. kirchbergensis. It is noteworthy that previous palaeontological/archaeological studies conducted in central and western Iran have suggested that most Iranian rhinoceros fossil/subfossil remains belong to Stephanorhinus (see Farshad, 1959; Mashkour et al., 2009), although some of these records may require verification.

Family EQUIDAE Gray, 1821

Genus EQUUS Linnaeus, 1758

Equus sp.

Figure 4.3-9, Table 1

Material. Three incisors $(\mathrm{QHJ}-12-14) ; 1$ right $\mathrm{M}^{3}$ (QHJ-22); 1 left $\mathrm{M}^{3}$ (?) (QHJ-42); 1 condyle part of left mandible (QHJ-47); 1 proximal part of humerus (QHJ-46).

Description. The referred incisors are long, triangular, with smooth crowns, with deep hollows in their occlusal surfaces. The last character suggests that the animal was juvenile. The ring of central enamel is narrow and nearer to the lingual border. Two of these teeth belong to the lateral side, because of the elliptical-shaped occlusal surfaces. The other one likely represents a medial tooth because it displays a circular occlusal surface (Figure 4.3-5).

A well-preserved right $\mathrm{M}^{3}$ displays a high crown. In occlusal view, the protocone is long and 
rounded, metacone is deeper and smaller than the paracone, and the parastyle is triangular (Figure 4.6-7). Another molar, presumably a left $\mathrm{M}^{3}$, is much more worn and most of the cusp and crenulation patterns are lost (Figure 4.8-9). The rest of material is tentatively referred to Equus.

Remark. We consider a caballoid horse is represented, because of the long and rounded protocone preserved on a $\mathrm{M}^{3}$ and the dimensions of these molars (Arceredillo, 2008).

\section{Order ARTIODACTYLIA Owen, 1848}

Family SUIDAE Gray, 1821

Suidae gen. et sp. indet. cf. Sus Linnaeus, 1758

Figure 4.10, Table 1

Material. Two phalanges (QHJ-27, 36).

Description. These phalanges are strongly developed and thick, and indistinguishable from those of modern Sus. One well-preserved sample may be a first phalange, as it displays a wider proximal part than the distal part and a widened distal edge (Figure 4.10).

Remarks. In Iran, the remains of Suidae from palaeontological/archaeological sites have been commonly referred to Sus sp. (e.g., those from Gar Arjaneh, $\mathrm{Pa}$ Sangar rockshelters, and Ghamari cave). Remains of Sus scrofa were also reported from several sites, such as the Gilvaran, Wezmeh, Bisitun, and Yafteh caves (Otte et al., 2007; Bazgir et al., 2014).

Family BOVIDAE Gray, 1821

Subfamily CAPRINAE Gray, 1821

Caprinae gen.et sp. indet. cf. Ovis aries Linnaeus, 1758

Figure 4.11-13, Table 1

Material. 1 left $M_{2}(Q H J-5) ; 1$ left mandible (QHJ44).

Description. In general, discrimination of bone remains from Ovis and Capra is difficult (Boesseneck, 1969). Among the Caprinae remains, putative $O$. aries samples include a left mandible retaining $\mathrm{P}_{4}$ (Figure 4.11) and an isolated left $\mathrm{M}_{2}$ (Figure 4.12-13) with a convex mesio-buccal edge (after the buccally projecting flange on the mesial corner). The character states of $\mathrm{M}_{2}$ are typical of O. aries, whereas in Capra, especially C. hircus (Linnaeus, 1758), the mesio-buccal edge is usually concave, and the disto-buccal lobe points in a strong posterior direction (Halstead et al., 2002; Gillis et al., 2011).

\section{Caprinae indet.}

Material. 2 lower right molars (QHJ-32, 33), 5 upper left molars (QHJ-36, 38-41), 1 proximal part of scapula (QHJ-31), 3 proximal parts of humeri (QHJ-27-29), 1 medial part of tibia (QHJ-30), 1 distal part of femur (QHJ-15), 1 distal part of metapodial (QHJ-17), and 2 phalanges ( $1^{\text {st }}$ and $2^{\text {nd }}$ ) (QHJ-18, 24).

Remarks. Caprinae indeterminate remains consist of 16 fragmentary cranial and postcranial remains (seven teeth fragments and nine limb bones). Remains of the subfamily Caprinae have been recorded from several palaeontological/archaeological sites in Iran. These sites include Haftovan tappeh (4 ka) and Tuwah Khoshkeh (6 ka) in western Iran, Qazvin plain (Zagheh, 6.3-7.2 ka; Qabrestan, 5-6.2 ka; Sagzabad, 2.4-4 ka), Sialk (4-8 ka), Jiroft (4-6 ka), and Tappeh Hesar (5 ka) in central Iran, and Shahre sokhteh (5 ka) in eastern Iran.

Subfamily BOVINAE Gray, 1821

Bovinae gen. et sp. indet. cf. Bos Linnaeus, 1758 Figure 4.15-16

Material. 1 left mandible (QHJ-1), 1 horn core (QHJ-26), 7 lumbar vertebrae (QHJ-4, 6-11), 1 condyle part of mandible (QHJ-34), and 6 upper molars and 1 premolar (QHJ-2, 3, 16, 19-21, 35).

Description. These fossils are referred to Bos based on their size and overall morphology. The horn core is hollow, broken, and only half of it was recovered. It displays a slight twist in the clockwise direction, with longitudinal grooves. It is concave in the central part, and the cross-section is elliptical. It has a short stem and circular base, and the curvature and torsion of the bone suggests that there might be a convergence between the horns in life (Figure 4.15-16).

Remark. The remains of Bos have been reported from several palaeontological/archaeological sites in Iran: Yafteh (35 ka), Warwazi caves, Gar Arjaneh, and $\mathrm{Pa}$ Sangar rockshelters (Otte et al., 2007).

Bovinae gen. et sp. indet. cf. Gazella De Blainville, 1816

Figure 4.17-18, Table 1

Material. 1 left $\mathrm{M}_{2}$ (QHJ-23); 1 tooth (QHJ-43). Description. The referred $M_{2}$ is poorly preserved. The enamel (mostly worn and broken) on the lingual side is thick. The posterior end of the protocone is moderately expanded, and the central cavities are wide and deep. The lingual wall of the tooth displays two distinct open valleys. A very small and transverse enamel layer connects the posterior end of the protocone with the hypocone. The metacone and the paracone are less broad than the hypocone and the protocone. The 

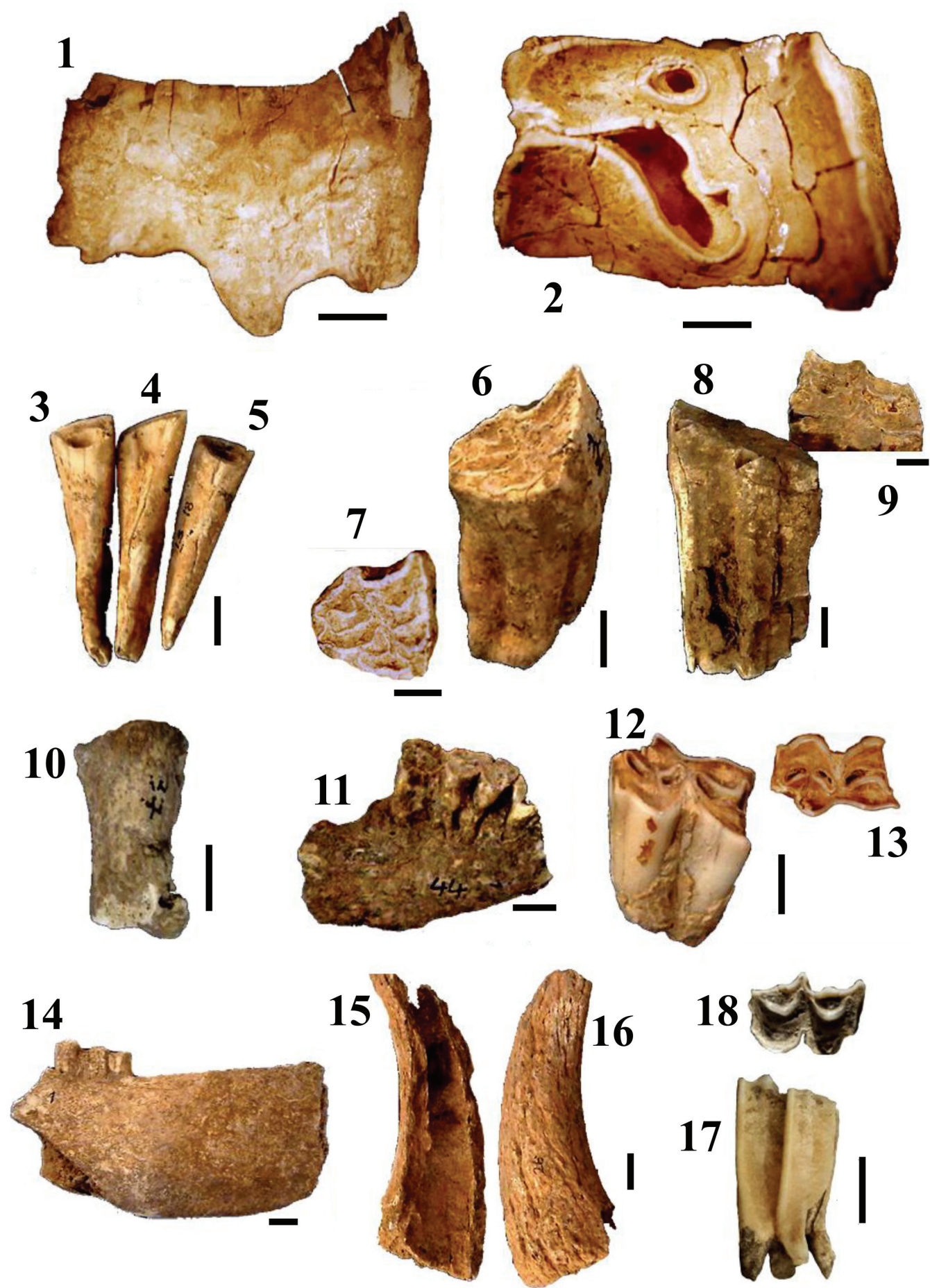

FIGURE 4. Photographs of selected vertebrate fossils from the Qalehjough fossil site. 1-2, a right $\mathrm{P}^{4}$ of Stephanorhinus cf. kirchbergensis (QHJ-45) in lateral (1) and occlusal (2) views. 3-5, three incisors of Equus (QHJ-12-14) in lateral views. 6-7, a right $\mathrm{M}^{3}$ of Equus (QHJ-22) in lateral (6) and occlusal (7) views. 8-9, a left $\mathrm{M}^{3}$ of Equus (QHJ-42) in lateral (8) and occlusal (9) views. 10, a first phalange of Sus (QHJ-37) in lateral view. 11, a left mandible of Ovis aries with $\mathrm{P}_{4}(\mathrm{QHJ}-44)$ in lateral view. 12-13, a left $\mathrm{M}_{2}$ of $O$. aries (QHJ-5) in lateral (12) and occlusal (13) views. 14, a left mandible of Bos (QHJ-1) in lateral view. 15-16, a horn core (mesiodistal part) of Bos (QHJ-26) in internal (15) and external (16) views. 17-18, a left $\mathrm{M}_{2}$ of Gazella (QHJ-23) in lateral (17) and occlusal (18) views. Scale bars equal 1 $\mathrm{mm}$. 
TABLE 1. Measurements of the Qalehjough fossils examined in this study. Abbreviations: BP, greatest breath of proximal end; Gbd, greatest breath of the distal end; GL, greatest length; GW, greatest width; HC, crown height; OL, occlusal length; OW, occlusal width; PL, protocone length; SB, smallest breath.

\begin{tabular}{|c|c|c|c|c|}
\hline \multirow{2}{*}{$\begin{array}{c}\text { Taxa } \\
\text { Stephanorhinus cf. kirchbergensis }\end{array}$} & \multirow{2}{*}{$\begin{array}{c}\text { Bone and teeth } \\
\text { Right } \mathrm{P}^{4}\end{array}$} & \multirow{2}{*}{$\begin{array}{c}\text { Specimen No. } \\
\text { QHJ-45 }\end{array}$} & \multicolumn{2}{|c|}{$\begin{array}{l}\text { Measurement } \\
(\mathrm{mm})\end{array}$} \\
\hline & & & $\mathrm{OL}$ & 59 \\
\hline & & & OW & 45 \\
\hline & & & $\mathrm{HC}$ & 40 \\
\hline \multirow[t]{13}{*}{ Equus sp. } & Incisor & QHJ-12 & GL & 50 \\
\hline & & & GW & 12 \\
\hline & Incisor & QHJ-13 & GL & 55 \\
\hline & & & GW & 15 \\
\hline & Incisor & QHJ-14 & GL & 55 \\
\hline & & & GW & 14 \\
\hline & Right $\mathrm{M}^{3}$ & QHJ-22 & OL & 31 \\
\hline & & & OW & 28 \\
\hline & & & PL & 10 \\
\hline & & & $\mathrm{HC}$ & 50 \\
\hline & Left $\mathrm{M}^{3}$ & QHJ-42 & $\mathrm{OL}$ & 42 \\
\hline & & & OW & 34 \\
\hline & & & $\mathrm{HC}$ & 59 \\
\hline \multirow[t]{4}{*}{ Suidae gen. et sp. indet. cf. Sus } & Phalange & QHJ-37 & GL & 35 \\
\hline & & & $\mathrm{BP}$ & 17 \\
\hline & & & SB & 12 \\
\hline & & & Gbd & 9 \\
\hline \multirow[t]{3}{*}{ Caprinae gen. et sp. indet. cf. Ovis aries } & Left $\mathrm{M}_{2}$ & QHJ-5 & GL & 45 \\
\hline & & & GW & 30 \\
\hline & Mandible & QHJ-44 & GL & 42 \\
\hline \multirow[t]{4}{*}{ Bovinae gen. et sp. indet. cf. Bos } & Mandible & QHJ-1 & GL & 150 \\
\hline & & & GW & 80 \\
\hline & Horn core & QHJ-26 & GL & 101 \\
\hline & & & GW & 39 \\
\hline \multirow[t]{2}{*}{ Bovinae gen. et sp. indet. cf. Gazella } & Left $\mathrm{M}_{2}$ & QHJ-23 & GL & 22 \\
\hline & & & GW & 14 \\
\hline
\end{tabular}

paracone is higher than the other cusps. The hypocone appears to be less crescentic because of the wear (Figure 4.17-18). These occlusal structures of the tooth strongly resemble those of Gazella. Other material includes an incomplete isolated tooth with strong wear on the occlusal surface and covering of hard cement. Based on overall morphology, it can also be referred to as Gazella sp.

Remarks. The remains of Gazella have been found from several palaeontological/archaeological sites in Iran: Buz Mordeh, Mohammad jafar, Ali Koush sites (4.9-6 ka), Yafteh cave (35 ka), and $\mathrm{Pa}$ Sangar rockshelter. Today, the Goitered gazelle, G. subgutturosa (Güldenstädt, 1780), is the most widespread Gazella species in Iran; it occurs in all over the country except for the north and some southern parts (Hemami, 1994; Karami et al., 2002). By contrast, G. dorcas (Linnaeus, 1758 ) is confined to eastern and south-eastern Iran. 
TABLE 2. The number of identified specimens (NISP) of fossils from the Qalehjough site.

\begin{tabular}{lcc}
\hline \multicolumn{1}{c}{ Taxa } & NISP & \% NISP \\
\hline Stephanorhinus cf. kirchbergensis & 1 & 2.1 \\
Equus sp. & 7 & 14.5 \\
Suidae gen. et sp. indet. cf. Sus & 2 & 4.3 \\
Caprinae gen. et sp. indet. cf. Ovis arie and Caprinae indet. & 18 & 38.5 \\
Bovinae gen. et sp. indet. cf. Bos & 17 & 36.3 \\
Bovinae gen. et sp. indet. cf. Gazella & 2 & 4.3 \\
\hline
\end{tabular}

\section{SPECIES COMPOSITION}

The mammal fossils from QHJ constituted four families in two orders, Perissodactyla (Rhinocerotidae and Equidae) and Artiodactyla (Suidae and Bovidae). The Bovidae was the predominant element in the QHJ fossil assemblage (NISP $=37$, $79.1 \%$ ). It was followed by Equidae (NISP $=7$, $14.5 \%$ ), Suidae (NISP $=2,4.3 \%$ ), and Rhinocerotidae $(\mathrm{NISP}=1,2.1 \%)$ (Table 2). Among the remains, 41 were fragmented (most of which belonged to the Bovidae [TNF $=34,89 \%$ ] and Equidae [TNF $=4,11 \%]$ ), whereas six were complete (three incisors of Equus, two phalanges of Sus, and a right $\mathrm{P}^{4}$ of Stephanorhinus).

\section{DISCUSSION}

As the composition of palaeofaunas may differ greatly from living communities, the relationships between fossil assemblages and paleoecology are usually not simple (Andrews, 1990). On the Iranian plateau, the reconstruction of palaeoclimate and palaeobiodiversity based on mammal remains is difficult because most data comes from western Iran, with only little published paleontological information available from the east. Thus every fossil find from this region, and any corresponding investigation into past conditions, contributes directly to understanding environmental changes during the late Quaternary of Iran.

The most interesting taxon identified from $\mathrm{QHJ}$, the extinct rhino Stephanorhinus, is perhaps the most informative. Niche differentiation between the two late Quaternary species S. kirchbergensis and S. hemitoechus (Falconer, 1868) has been frequently suggested, with the former preferring closed forest or woodland habitats and the latter adapted to more open habitats (e.g., Stuart, 1991; Fortelius et al., 1993; Pushkina, 2007). However, an analysis of the dietary preferences of both species in northwestern Europe suggested they were characteristic of mixed feeders similar to extant mammals occupying more open habitats (van Asperen, 2010; van Asperen and Kahlke, 2015). Biogeographical data is a little less contradictory with regards to likely habitat preferences of this genus. In Eurasia, Pushkina (2007) indicated that neither late Pleistocene Stephanorhinus species were recorded in more open and arid landscapes (specifically, those beyond $55^{\circ} \mathrm{N}$ ), while the most southern record of Stephanorhinus, from Shennongjia, Hubei, China (Tong and Wu, 2010), suggests that it inhabited high altitude temperate deciduous and coniferous forests. The Stephanorhinus tooth recovered from $\mathrm{QHJ}$, although only partially preserved, exhibits heavy wear, suggesting that this individual consumed an abrasive diet consistent with more open than heavily forested habitats. The closest extant rhinoceroses in the region, the Indian rhino Rhinoceros unicornis, is a grazer preferring riverine habitats such as the Indus river of North Pakistan, from Behra on the Jhalum river in the east, westwards to Peshawar, and as far as the Khyber pass near Kabol and the boundary between Afghanistan and Pakistan (Rookmaker, 2000).

Horse remains from the western, northwestern, and the central part of Iran include Qabrestan (5-6.2 ka) with Equus ferus, E. hemionus, E. asinus, and E. hydrantinus; Sagzabad (2.4-4 ka) with all the aforementioned species but also $E$. caballus; and Zagheh (6.3-7.2 ka) with E. ferus; $E$. hemionus, and $E$. hydrantinus (Bocherens et al., 2000). Wild horses living during glacial and interglacial environments extended to forest-steppe environments (Koenigswald, 2003). They were capable of living in quite diverse environments, from hot to cold environments on glacial steppes to forests during interglacial periods (van Asperen, 2010). However, dental and postcranial morphological differences between caballoid and asinid horses represent adaptations to fundamentally different habitats, with caballoid horses better adapted to, and perhaps indicative of, more humid, 
closed and often cooler environments (van Asperen et al., 2012).

While modern climatic data from the region surrounding $\mathrm{QHJ}$ indicates that this area receives minimal rain and is relatively dry (less than $100 \mathrm{~mm}$ per year) (Kehl, 2009), the presence of Stephanorhinus cf. kirchbergensis and a caballoid horse suggests that the palaeoenvironment at $\mathrm{QHJ}$ was more humid with open woodlands. This suggestion is supported by numerous deep and wide valleys on the northern and southern slope of Cheltan Mountain, suggesting higher rainfall in the past; and the density of zooarchaeological remains in karstic caves such as Mapary near QHJ (Darvish and Labbaf Khanik, 2003) suggesting a landscape able to support a higher biomass than today.

Stephanorhinus is a characteristic member of the 'Palaeoloxodon antiquus' fauna, an assemblage typifying Middle and Late Pleistocene interglacials of Europe (Kahlke, 1986; Azzaroli et al., 1988; Stuart, 1991; Bradshaw et al., 2003; Pushinka, 2007). This faunal assemblage is best known from western and central Europe, although Stephanorhinus has a wide geographical distribution throughout Eurasia and into eastern China (Pushkina, 2007; Billia and Zervanová, 2014), and became globally extinct in the late Weichselian (Pushinka, 2007). While a direct age for the QHJ fossils hasn't yet been determined, on the basis of the presence of Stephanorhinus it seems likely to represent an interglacial Middle to Late Pleistocene faunal assemblage.

While preliminary, our study suggests that during interglacials at least, eastern Iran was significantly more humid and vegetated than today. These conditions would have facilitated the migration of large herbivorous mammals between the Mediterranean, eastern Europe, and central Asia. For example, Pushkina (2007) proposed one of two routes for Stephanorhinus into China: the first through southern Russia and Kazakhstan to Lake Baikal, then south into China along river valleys; the second via a southern route around the Tibetan plateau. While neither suggested route is invalidated by our find, the presence of Stephanorhinus in eastern Iran tends to support the second, more southerly route. The loss of taxa such as Stephanorhinus and the caballoid horse from eastern Iran are likely due to their larger body sizes and lower reproductive rates negatively impacted by habitat loss, in particular the development of clay deserts, vegetation decline, and reduction of water sources occurring since the time of deposition of QHJ. These changes would have resulted in decreasing population sizes (e.g., King and Saunders, 1984; Guthrie, 2003) and ultimately extinction.

\section{ACKNOWLEDGEMENT}

We thank the International Campus University of Ferdowsi University of Mashhad for support of this project. We are grateful to the Museum of this University and Labbaf the head of the ICHTO (Iranian Cultural Heritage and Tourism Organization, Khorasan Razavi Province) for helping with this project. Anonymous reviewers provided valuable comments that helped improve this manuscript.

\section{REFERENCES}

Alijani, B., Ghohroudi, M., and Arabi, N. 2008. Developing a climate model for Iran using GIS. Theoretical and Applied Climatology, 92:103-112.

Andrews, P. 1990. Ow/s, Caves and Fossils. Natural History Museum Publications, London.

Arceredillo, D. 2008. Morphometric Differences among the Equids of the Upper Pleistocene from Valdegoba (Burgos, Spain). Bulletin of the International Association for Paleodontology, 2:21-6.

Azzaroli, A., de Giuli, C., Ficcarelli, G., and Torre, D. 1988. Late Pliocene to early Mid-Pleistocene mammals in Eurasia: faunal succession and dispersal events. Palaeogeography, Palaeoclimatology, Palaeoecology, 66:77-100.

Barnosky, A.D. 1986. Taphonomy and herd structure of the extinct Irish elk, Megaloceros giganteus. Science, 228:340-44.

Barnosky, A.D. 1989. The Late Pleistocene event as a paradigm for widespread mammal extinction, p. 235255. In Donovan, S.K. (ed.), Mass Extinctions: Processes and Evidence. Columbia University Press, New York.

Bazgir, B., Otte, M., Tumung, L., Ollé, A., Deo, S.G., Joglekar, J., López-Garca, J.M., Picin, A., Davoudi, D., and Van der Made, J. 2014. Test excavations and initial results at the middle and upper Paleolithic sites of Gilvaran, Kaldar, Ghamari caves and Gar Arjene rockshelter, Khorramabad valley, western Iran: Gilvaran, Kaldar, Ghamari, Gar Arjeneh. Comptes Rendus Palevol, 13:511-525.

Billia, E.M.E. and Zervanová, J. 2014. New Stephanorhinus kirchbergensis (Jäger, 1839) (Mammalia, Rhinocerotidae) records in Eurasia. Addenda to a previous work. Gortania. Geologia, Paleontologia, Paletnologia, 36:55-68.

Bocherens, H., Mashkour, M., and Billiou, D. 2000. Palaeoenvironmental and archaeological implications of isotopic analyses $(13 \mathrm{C}, 15 \mathrm{~N})$ from Neolithic to present in Qazvin plain (Iran). Environmental Archaeology, 15:1-19.

Boddaert, P. 1785. Elenchus Animalium. Volumen I Sistens Quadrupedia huc usque nota, eorumque varietates. Hake, Rotterodami. 
Boessneck, J. 1969. Osteological differences between sheep (Ovis aries Linné) and Goats (Capra hircus Linné), p. 331-358. In Brothwell, D.R. and Higgs, E.S. (eds.), Science in Archaeology: A Comprehensive Survey of Progress and Research. Thames \& Hudson, London.

Bradshaw, R.H.W., Hannon, G.E., and Lister, A.M. 2003. A long term perspective on ungulate-vegetation interactions. Forest Ecology and Management, 181:267280.

Buitenhuis, H. 1995. A Quantitative approach to species determination of Ovicapridae, p. 140-155. In Buitenhuis, H. and Uerpmann, H.P. (eds.), Archaeozoology of the Near East II. Backhuys, Leiden.

Darvish, J. and Labbaf Khanik, R. 2003. Paleozoology of Kavir Namak in archaeological finding of Mapari and Ghaleh jough cave, p. 35-45. In Azarnoush, M. (ed.), The First Symposium of Archaeometry in Iran: The Role of the Science in Archaeology, Archaeological Research Center, Tehran.

De Blainville, H.M.D. 1816. Prodrome d'une nouvelle distribution systématique du règne animal. Bulletin des Sciences, 8:105-124. (In French)

Deng, T. 2008. Comparison between woolly rhino forelimbs from Longdan, north western China and Tologoi, Transbaikalian region. Quaternary International, 179:196-207.

Deng, T. 2009. Late Cenozoic environmental changes in the Linxia basin (Gensu, China) as indicated by mammalian cenograms. Vertebrata Palasiatica, 47:282-298.

Eisenmann, V. 1986. Comparative osteology of modern and fossil horses, half-asses and asses, p 67-116. In Meadow, R.H. and. Uerpmann, H.P. (eds.), Equids in the Ancient World. Dr. Ludwig Reichert Verlag, Wiesbaden.

Faith, J.T. 2014. Late Pleistocene and Holocene mammal extinctions on continental Africa. Earth Science Reviews, 128: 105-121.

Falconer, H. 1868. On the European Pliocene and PostPliocene Species of the Genus Rhinoceros, p. 309403. In Murchison, C. (ed.), Palaeontological Memoirs and Notes of the Late Hugh Falconer, Volume 2. Spottiswoode and Co., London.

Farshad, F. 1959. Vertebrate Paleontology, Tehran University Press, Tehran.

Ficcarelli, G., Coltorti, M., Moreno-Espinosa, M., Pieruccini, P.L., Rook, L., and Torre, D. 2003. A model for the Holocene extinction of the mammal megafauna in Ecuador. Journal of South American Earth Science, 15:835-845.

Forster, M.A. 2004. Self organised instability and megafaunal extinctions in Australia. Oikos, 103:235-39.

Fortelius, M., Mazza, P., and Sala, B. 1993. Stephanorhinus (Mammalia: Rhinocerotidae) of the western European Pleistocene, with a revision of $S$. etruscus (Falconer, 1868). Palaeontographia Italica, 80:63155.
Gillis, R., Chaix, L., and Vigne, J.D. 2011. An assessment of morphological criteria for discriminating sheep and goat mandibles on a large prehistoric archaeological assemblage (Kerma, Sudan). Journal of Archaeological Science, 38: 2324-2339.

Graham, R.W. and Lundelius, E.L., Jr. 1984. Coevolutionary disequilibrium and Pleistocene extinctions, $p$. 223-249. In Martin, P.S. and Klein, R.G. (eds.), Quaternary Extinctions: A Prehistoric Revolution. University of Arizona Press, Tucson.

Gray, J.E. 1821. On the natural arrangement of vertebrose animals. The London Medical Repository Monthly. Journal Review, 15:296-310.

Güldenstädt, J.A. 1780. Antilope subgutturosa descripta. Acta Academiae scientiarum imperialis petropolitanae, 1778(1):251-274. (In Latin)

Guthrie, R.D. 1984. Mosaics, allelochemicals and nutrients: an ecological theory of Late Pleistocene megafaunal extinctions, p. 259-298. In Martin, P.S. and Klein, R.G. (eds.), Quaternary Extinctions: A Prehistoric Revolution. University of Arizona Press, Tucson.

Guthrie, R.D. 2003. Rapid body size decline in Alaskan Pleistocene horses before extinction. Nature, 426:169-171.

Halstead, P., Collins, P., and Issakidou, V. 2002. Sorting sheep from the goats: morphological distinction between the mandibles and mandibular teeth of adult Ovis and Capra. Journal of Archaeological Science, 29:545-553.

Hashemi, N. 2006. Discovery of rhinoceros teeth fossil in Quaternary sediments, margin desert namak, to look on paleoenviroment, p. 228, $10^{\text {th }}$ Symposium of Geological Society of Iran. Tarbiat Modares University, Tehran.

Hashemi, N. 2012. The Study of large assemblage of Quaternary of bird remains of western Iran, p. 253, 31th Symposium of Geological survey and mineral exploration of Iran, Tehran.

Hashemi, N. and Darvish, J. 2008. The identification of a new mammal fossils fauna in Pleistocene sediments of eastern Iran and compression it,s to Maragheh fauna, to look on paleoinviroment, Geosciences Scientific Quarterly Journal, 66:108-115.

Hashemi, N., Darvish, J., Mashkour, M., and Biglari, F. 2006. Rodents and Lagomorphs remains from Late Pleistocene and Early Holocene caves and rockshelters sites in the Zagros region, west, and north best of Iran. Iranian Journal of Animal Biosystematics, 2:25-33.

Hashemi, N., Vigne, J.D., Bailon, S., Roustaie, K., Rezvai, H., Darvish, J., and Mashkour, M. 2010. Preliminary results of the study of the small vertebrates of Kani Mikaiel cave (western Iran; 20,000 BP to historical times), 11th ICAZ Conference, International counical for Archeozoology, Université Paris VI (Pierre and Marie Curie), Muséum National d'Histoire Naturelle Paris, France.

Helmer, D. and Rocheteaux, M. 1994. Atlas appendiculaire des principaux genres Holocènes de petits rumi- 
nants du nord de la Méditerranée et du proche-orient (Capra, Ovis, Rupicapra, Capreolus, Gazella). In: Fiches d'ostéologie animale pour l'archéologie Série $B$, Mammifères, APDCA, Juan- les-Pins. (In French)

Hemami, M.R. 1994. Taxonomic Status and Distribution of Iranian Gazelles. MSc thesis, University of Tehran, Iran.

Hillson, S. 1986. Teeth. Cambridge Manuals in Archaeology. Cambridge University Press, Cambridge.

Jäger, G.F. 1839. Über die fossilen Säugetiere welche in Württemberg in verschiedenen Formationen aufgefunden worden sind, nebst geognotischen Bemerkungen über diese Formtionen. C. Erhard Verlag, Stuttgart. (In German)

Kahlke, H.D. 1986. Biostratigraphical correlations (mammals) of the Quaternary continental deposits of Europe and the Far East. Quartär paläontologie, 6:83-86.

Karami, M., Hemami, M.R., and Groves, C.P. 2002. Taxonomy, distribution and ecology of the gazelles in Iran. Zoology in the Middle East, 26:29-36.

Kehl, M. 2009. Quaternary Climate Change in Iran-The state of Knowledge. Erdkunde, 63:1-17.

King, J.E. and Saunders, J.J. 1984. Environmental insularity and the extinction of the American mastodont, p. 315-339. In Martin, P.S. and Klein, R.G. (eds.), Quaternary Extinctions: A Prehistoric Revolution. University of Arizona Press, Tucson.

Koenigswald, W.v. 2003. Mode and cause for the Pleistocene turnovers in the mammalian fauna of Central Europe. Deinsia, 10:305-312.

Kretzoi, M. 1942. Präokkupierte und durch ältere zu ersetzende Säugetiernamen. Földtani Közlöny, 72:345-349. (In German)

Lacombat, F. 2006. Morphological and biometrical differentiation of the teeth from Pleistocene species of Stephanorhinus (Mammalia, Perissodactyla, Rhinocerotidae) in Mediterranean Europe and the Massif Central, France. Palaeontographica Abteilung, 274:71-111.

Linnaeus, C. 1758. Systema naturae per regna tria naturae, secundum classes, ordines, genera, species, cum characteribus, differentiis, synonymis, locis, Tomus I. Editio decimal, refomata. Salvius, Stockholm. (In Latin)

Louys, L. 2014. The large terrestrial carnivore guild in Quaternary Southeast Asia. Quaternary Science Reviews, 96:86-97.

Louys, J., Curnoe, D., and Tong, H. 2007. Characteristics of Pleistocene megafauna extinctions in Southeast Asia. Palaeogeography, Palaeoclimatology, Palaeoecology, 243:152-173.

MacPhee, R.D.E. 1999. Extinctions in Near Time: Causes, Contexts, and Consequences. New York., Kluwer Academic/Plenum Publishers.

Martin, P.S. and Klein, R.G., eds. 1984. Quaternary Extinctions: A prehistoric revolution, University of Arizona Press, Tucson.
Mashkour, M., Monchot, H., Trinkaus, E., Reyss, J., Biglari, F., Bailon, S., Heydari, S., and Abdi, K. 2009. Carnivores and their prey in the Wezmehcave (Kermanshah, Iran): A Late Pleistocene refuge in the Zagros. International Journal of Osteoarchaeology, 19:678-694.

Mirzaie Ataabadi, M. 2000. Preliminary study of Elephant teeth remains from Quaternary sediment of Ravansar region, (page numbers unknow). In Taheri, K. (ed.), Ravansar: Paleoanthropology, Geology, Geography and Culture. Taghebostan press. Taghebostan.

Moradi, H., Joshi, J. and Schmid, B. 2010. Biological variables in Iranian EISs, 'IAIA10 Conference Proceedings' The Role of Impact Assessment in Transitioning to the Green Economy, 30th Annual Meeting of the International Association for Impact Assessment, International Conference Centre Geneva, Switzerland.

Mosimann, J.E. and Martin, P.S. 1975. Simulating overkill by paleoindians. American Science, 63:304-313.

Otte, M., Biglari, F., Flas, D., Shidrang, S., Zwyns, N., Mashkour, M., Naderi, R., Mohasb, A., Hashemi, N., Darvish, J., and Radu, V. 2007. The Aurignacian in the Zagros region new research at Yafteh cave, Lorestan, Iran. Antiquity, 81:82-96.

Owen, R. 1848. On the Archetype and Homologies of the Vertebrate Skeleton. Voorst, London.

Pallas, P.S. 1775. Equus hemionus, mongolis dshikketaei dictus. Academie Sciences Petropoli [St. Petersburg], 19:394-417.

Payne, S. 1969. A metrical distinction between sheep and goat metacarpals, p. 295-305. In Ucko, P.J. and Dimbleby, G.W. (eds.), The Domestication and Exploitation of Plants and Animals, London, Duckworth.

Prummel, W. and Frisch, H.J. 1986. A guide for the distinction of species, sex and body side in bones of sheep and goat. Journal of Archaeological Science, 13:567-577.

Pushinka, D. 2007. The Pleistocene easternmost distribution in Eurasia of the species associated with the Eemian Palaeoloxodonantiquus assemblage. Mammal Review, 37:224-245.

Redding, W.R. 1978. Rodents and the archaeological palaeoenvironment: Considerations, problems and future. Peabody Museum Bulletin, 2:63-68.

Regàlia, E. 1907. Sull'Equus (Asinus) hydruntinus Regalia della grotta di Romanelli (Castro, Lecce). Archivio per l'Antropologiae l'etnologia, 37:375-390. (In Italian)

Rookmaker, L.C. 2000. Records of the Rhinoceros in Pakistan and Afghanistan. Pakistan Journal Zoology, 32:65-74.

Stuart, A.J. 1991. Mammalian extinctions in the Late Pleistocene of northern Eurasia and north America. Biological Reviews, 66:453-562.

Stuart, A.J. 1999. Late Pleistocene megafaunal extinctions, p. 257-269. In Macphee, R.D.E (ed.), Extinctions in Near Time: Causes, Contexts, and 
Consequences. New York., Kluwer Academic/Plenum Publishers.

Stuart, A.J., Kosintsev, P., Higham, T., and Lister, A. 2004. Pleistocene to Holocene extinction dynamics in giant deer and woolly mammoth. Nature, 431:684689.

Tong, H.W. and Wu, X.Z. 2010. Stephanorhinus kirchbergensis (Rhinocerotidae, Mammalia) from the Rhino Cave in Shennongjia, Hubei. Chinese Science Bulletin, 55:1157-1168.

Van Asperen, E.N. 2010. Ecomorphology and migratory behaviour of Late Middle Pleistocene horses in northwest Europe. Palaeogeography, palaeoclimatology, palaeoecology, 297:584-596.

Van Asperen, E.N. and Kahlke, R.D. 2015. Dietary variation and overlap in Central and Northwest European Stephanorhinus kirchbergensis and S. Hemitoechus (Rhinocerotidae, Mammalia) influenced by habitat diversity. Quaternary Science Reviews, 107:47-61.

Van Asperen, E.N., Stefaniak, K., Proskurnyak, I., and Ridush, B. 2012. Equids from Emine-Bair-Khosar
Cave (Crimea, Ukraine): co-occurrence of the stenonid Equus hydruntinus and the caballoid $E$. ferus latipes based on skull and postcranial remains. Palaeontologia Electronica 15.1.5A:1-28 palaeoelectronica.org/content/2012-issue-1-articles/124equids-from-emine-bair-khosar

Von den Driesch, A. 1976. A Guide to the Measurement of Animal Bones from Archaeological Sites. Harvard University, Peabody Museum of Archaeology and Ethnology, Cambridge.

Wroe, S., Field, J.H., Archer, M., Grayson, D.K., Price, G.J., Louys, J., Faith, J.T., Webb, G.E., and Mooney, S.D. 2013. Climate change frames debate over the extinction of megafauna in Sahul (Pleistocene Australia-New Guinea). Proceedings of the National Academy of Sciences, USA, 110:8777-8781.

Zeder, M.A. and Lapham, H.A. 2010. Assessing the reliability of criteria used to identify postcranial bones in sheep, Ovis and goats, Capra. Journal of Archaeological Science, 37:2887-2905. 